\title{
ENDOMYOCARDIAL FIBROSIS IN BAHIA, BRAZIL
}

\author{
BY \\ ZILTON A. ANDRADE AND ARMENIO C. GUIMARÃES \\ From the Departments of Pathology and Internal Medicine, University of Bahia School of Medicine, \\ Bahia, Brazil
}

Received April 9, 1964

Endomyocardial fibrosis was originally reported as a prevalent condition leading to fatal cardiac failure in Uganda (Davies, 1960; Shillingford and Somers, 1961). Shortly afterwards, reports of new cases came from other African regions (Turner and Manson-Bahr, 1960; Abrahams, 1962) and isolated cases were recognized in America (Ishak and Tschumy, 1962), Europe (Lynch and Watt, 1957; Faruque, 1963), and Asia (Nagaratnam and Dissanayake, 1959). Great interest has been attached to the geographical distribution of this condition, as it may give a clue to the problems of ætiology and pathogenesis which are still obscure. In Brazil, the disease has been recently reported in the southern state of Rio Grande do Sul (Mattos et al., 1963; Fagundes, 1963). We have 4 cases of endomyocardial fibrosis in Bahia, a northern state. As this region of Brazil has some ethnic and socio-economic resemblance to the African regions in which endomyocardial fibrosis has been reported, it was considered worth while to publish these cases.

\section{SubJeCts AND MeTHOdS}

Clinical and necropsy records from 4 cases of endomyocardial fibrosis were studied and their data tabulated. All necropsies were complete and the hearts and fragments of several other organs were fixed in neutral 10 per cent formalin. Paraffin sections were submitted to the following stain methods: hæmatoxylin and eosin, Mallory's blue anilin for connective tissue, a combination of Weigert van Gieson methods for both collagen and elastic tissues, Gomori's silver method for reticulum, the PAS method, and Gomori's trichrome stain.

\section{RESULTS}

Clinical Findings. The main clinical data are presented in Table I. All patients gave a past history of progressive exertional dyspnœa, œdema, and ascites. The ascites appeared after the first two symptoms and was always refractory to the usual therapeutic measures. Paroxysmal nocturnal dyspnœa was reported by Case 4 only. In none of these cases were there symptoms suggestive of pulmonary embolism. Characteristically, the manifestations of heart failure were of long duration, with an average of six years. On physical examination there was no fever and the blood pressure was within normal limits, with a low differential in Case 4. All patients presented massive œdema of the legs, hepatosplenomegaly and ascites. On examination of the heart in all cases, except Case 1, the point of maximal impulse was not palpable, the sounds were muffled, and there were no murmurs. Case 3 had a large pericardial effusion, and was tapped several times. In Case 1 the point of maximal impulse of the heart was palpable on the sixth left intercostal space over the anterior axillary line; the pulmonary second sound was loud and a systolic murmur, regurgitant in type, 3/4 in intensity, was heard between the left lower border of the sternum and the mitral area; in the same area a protodiastolic murmur, $1 / 4$ to $2 / 4$ in intensity, was also heard. Two 
TABLE I

Clinical Data on Four Cases of Endomyocardial Fibrosis

\begin{tabular}{|c|c|c|c|c|c|c|}
\hline \multicolumn{3}{|c|}{$\begin{array}{l}\text { Case No, age, } \\
\text { and sex }\end{array}$} & Race & $\begin{array}{c}\text { Duration } \\
\text { (years) }\end{array}$ & Initial symptoms & Principal symptoms \\
\hline 1 & 27 & $\mathbf{M}$ & Negro & 2 & $\begin{array}{l}\text { Dizziness; pain in the epigastric } \\
\text { region and in the right upper } \\
\text { quadrant }\end{array}$ & $\begin{array}{l}\text { Exertional dyspnœa; cough; œdema } \\
\text { of the legs; ascites }\end{array}$ \\
\hline 2 & 24 & $\mathbf{F}$ & Negro & 7 & $\begin{array}{l}\text { Exertional dyspnœa; epigastric } \\
\text { pain radiating to right and left } \\
\text { upper quadrants }\end{array}$ & $\begin{array}{l}\text { Exertional dyspnœa; orthopnœa; } \\
\text { œdema of legs; ascites }\end{array}$ \\
\hline 3 & 29 & $\mathbf{M}$ & Negro & 13 & Cough & $\begin{array}{l}\text { Exertional dyspnœa; precordial } \\
\text { pain; œdema of legs; ascites }\end{array}$ \\
\hline 4 & 28 & $\mathrm{~F}$ & White & 2 & $\begin{array}{l}\text { Generalized œdema; exertional } \\
\text { dyspnœa; cough }\end{array}$ & $\begin{array}{l}\text { Exertional dyspnœa, nocturnal; } \\
\text { paroxysmal dyspnœa; œdema of } \\
\text { legs; ascites }\end{array}$ \\
\hline
\end{tabular}

TABLE II

Principal Laboratory Data

\begin{tabular}{|c|c|c|c|c|c|c|}
\hline $\begin{array}{l}\text { Case } \\
\text { No. }\end{array}$ & $\begin{array}{l}\text { Venous } \\
\text { pressure } \\
\text { (cm.) }\end{array}$ & $\begin{array}{c}\mathrm{Hb} \\
(\mathrm{g} . / 100 \\
\mathrm{ml} .)\end{array}$ & 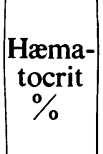 & Leucocyte count & $\begin{array}{l}\text { Proteins } \\
\text { (g. } / 100 \mathrm{ml} .)\end{array}$ & $\begin{array}{l}\text { Complement- } \\
\text { fixation } \\
\text { reaction for } \\
\text { Chagas' } \\
\text { disease }\end{array}$ \\
\hline 1 & 47 & $13 \cdot 2$ & 39 & $\begin{array}{l}5800 ; \text { neutrophils, } 61 \% ; 5 \% \\
\text { band forms; eosinophils, } 9 \% \\
\text { lymphocytes, } 21 \% \text {; mono- } \\
\text { cytes, } 9 \%\end{array}$ & $\begin{array}{l}7 \cdot 0: \text { albumin, } 3 \cdot 3 ; \text { globu- } \\
\text { lin, } 3 \cdot 7\end{array}$ & Negative \\
\hline 2 & 30 & $9 \cdot 0$ & 32 & $\begin{array}{l}4000 ; \text { neutrophils, } 58 \% ; 8 \% \\
\text { band forms; eosinophils, } \\
11 \% \text {; lymphocytes, } 28 \% \\
\text { monocytes, } 3 \%\end{array}$ & $\begin{array}{l}5 \cdot 6: \text { albumin, } 2 \cdot 7 \text {; globu- } \\
\text { lin, } 2 \cdot 9\end{array}$ & Negative \\
\hline 3 & 27 & $13 \cdot 6$ & 48 & $\begin{array}{l}2800 ; \text { neutophils, } 59 \% ; 1 \% \\
\text { band forms; eosinophils, } 3 \% \\
\text { lymphocytes, } 29.5 \% \text {; mono- } \\
\text { cytes, } 7.5 \%\end{array}$ & $\begin{array}{l}7 \cdot 2 \text { : albumin, } 5 \cdot 3 ; \text { globu- } \\
\quad \text { lin, } 1 \cdot 8\end{array}$ & \\
\hline 4 & 一 & $14 \cdot 0$ & 51 & $\begin{array}{l}6000 ; \text { neutrophils, } 65 \% ; 6 \% \\
\text { band forms; eosinophils, } 2 \% \text {; } \\
\text { lymphocytes, } 21 \% \text {; mono- } \\
\text { cytes, } 2 \%\end{array}$ & $\begin{array}{l}5 \cdot 6: \text { albumin, } 3 \cdot 1 \text {; globu- } \\
\quad \text { lin, } 2 \cdot 5\end{array}$ & Negative \\
\hline
\end{tabular}

patients (Cases 2 and 4) had pleural effusions. All except Case 3 showed cyanosis in the extremities associated with clubbed fingers. The principal laboratory findings are presented in Table II.

The venous pressure recorded in three patients was very high; the leucocyte count was low in Case 3 while Cases 1 and 2 showed a very high eosinophil count. The serum albumin level was low in all but one (Case 3). Case 1 presented an associated increase of serum globulin. Electrocardiographic findings are shown in Table III. The most frequent electrocardiographic alteration observed was the low voltage of the QRS complex, which was present in all. This type of alteration sometimes occurred in all leads (Cases 2 and 3, Fig. 1), in frontal plane leads only (Case 1), or in frontal plane leads plus VI, V5, and V6 (Case 4). In Case 3, after the surgical drainage of the pericardial effusion, the low voltage of the QRS complex was observed in leads VI, V5, and V6 only. 
TABLE III

ELECTROCARDIOGRAPHIC FINDINGS

\begin{tabular}{|c|c|c|c|c|c|c|c|c|c|c|}
\hline $\begin{array}{l}\text { Case } \\
\text { No. }\end{array}$ & Rhythm & Rate & $\underset{(\mathrm{sec} .)}{P}$ & $\begin{array}{c}\text { PR } \\
\text { (sec.) }\end{array}$ & $\begin{array}{l}\text { QRS } \\
\text { (sec.) }\end{array}$ & $\begin{array}{l}\text { QTC } \\
\text { (sec.) }\end{array}$ & SÂP & SÂQRS & SÂT & Final conclusions \\
\hline 1 & $\begin{array}{l}\text { Sinus with isolated } \\
\text { ventricular prema- } \\
\text { ture beats, first } \\
\text { degree A-V block } \\
\end{array}$ & $\begin{array}{l}75 / \\
\text { min. }\end{array}$ & $0 \cdot 14$ & $0 \cdot 30$ & 0.08 & 0.412 & $+50^{\circ} \ddagger$ & $+120^{\circ} \ddagger$ & $40^{\circ} \mathrm{A}^{*}$ & $\begin{array}{l}\text { Intra-atrial conduc- } \\
\text { tion defect RBBB? } \\
\text { ischæmic waves on } \\
\text { the antero-lateral } \\
\text { region; low vol- } \\
\text { tage of QRS } \\
\text { complex in frontal } \\
\text { plane leads }\end{array}$ \\
\hline 2 & Atrial fibrillation & $\begin{array}{l}75 / \\
\text { min. }\end{array}$ & & & 0.06 & & & $+100^{\circ} \mathrm{P}^{*}$ & $5^{\circ} \mathbf{P}$ & $\begin{array}{l}\text { Low voltage of } P \\
\text { wave and of ven- } \\
\text { tricular complex } \\
\text { in all leads }\end{array}$ \\
\hline 3 & $\begin{array}{l}\text { Sinus } \\
\text { After surgical drain- } \\
\text { age of pericardial } \\
\text { sac: }\end{array}$ & $\begin{array}{l}94 / \\
\text { min. }\end{array}$ & 0.08 & $0 \cdot 16$ & 0.07 & 0.415 & $+60^{\circ} \mathrm{A}$ & $+20^{\circ} \mathrm{A}$ & $+20^{\circ} \mathrm{A}$ & $\begin{array}{l}\text { Low voltage of } \\
\text { QRS complex in } \\
\text { all leads }\end{array}$ \\
\hline & Sinus & $\begin{array}{l}70 / \\
\text { min. }\end{array}$ & $0 \cdot 11$ & $0 \cdot 20$ & 0.09 & $0 \cdot 388$ & $+70^{\circ} \mathrm{A}$ & $+80^{\circ} \mathrm{A}$ & $+10^{\circ} \mathrm{P}$ & $\begin{array}{l}\text { QRS complex re- } \\
\text { mains of low vol- } \\
\text { tage in V1, V5, } \\
\text { and } \mathrm{V} 6\end{array}$ \\
\hline 4 & $\begin{array}{l}\text { Flutter with } 2: 1 \\
\text { A-V block, isola- } \\
\text { ted ventricular } \\
\text { premature beats }\end{array}$ & $\begin{array}{l}100 / \\
\text { min. }\end{array}$ & & & 0.07 & & & $+115^{\circ} \mathrm{P}$ & $+50^{\circ} \mathrm{A}$ & $\begin{array}{l}\text { Low voltage of } P \\
\text { wave and of ven- } \\
\text { tricular complex } \\
\text { in frontal plane } \\
\text { leads; low voltage } \\
\text { of QRS complex } \\
\text { in V1, V5, and } \\
\mathrm{V} 6\end{array}$ \\
\hline
\end{tabular}

* Position of the vector in the horizontal plane

A, anterior direction

$\dagger=$ same direction of the frontal plane

$\mathbf{P}$, posterior direction

¥ RBBB = right bundle-branch block

On radiological examination the cardiac shadow was grossly enlarged resembling a large pericardial effusion. Pericardial effusion was definitely demonstrated in two patients (Cases 2 and 3). In Case 3, the diagnosis of pericardial effusion was made during life, and after all the fluid was drained surgically, we could see on radiograph a cardiac shadow slightly smaller than normal. In three cases (2, 3, and 4) a striking feature was the aspect of the inferior right arch of the cardiac silhouette revealing a great enlargement of the right atrium (Fig. 2). The pulmonary circulation was diminished in all cases. Cases 2 and 4 presented associated pleural effusion on the right side.

Pathological Findings. Gross extracardiac findings are presented in Table IV. The peritoneal lining was somewhat opaque, but smooth and glistening, and no adhesions of intestinal loops were found except in Case 3
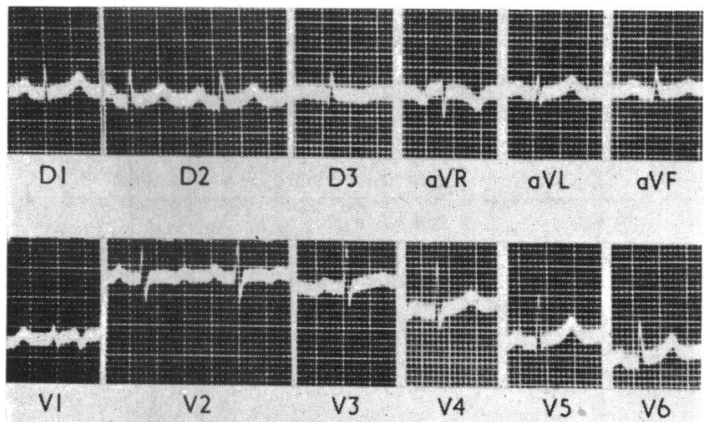

FIG. 1.-Electrocardiogram of Case 3 before pericardial drainage. Note low voltage of QRS complexes in all leads. 


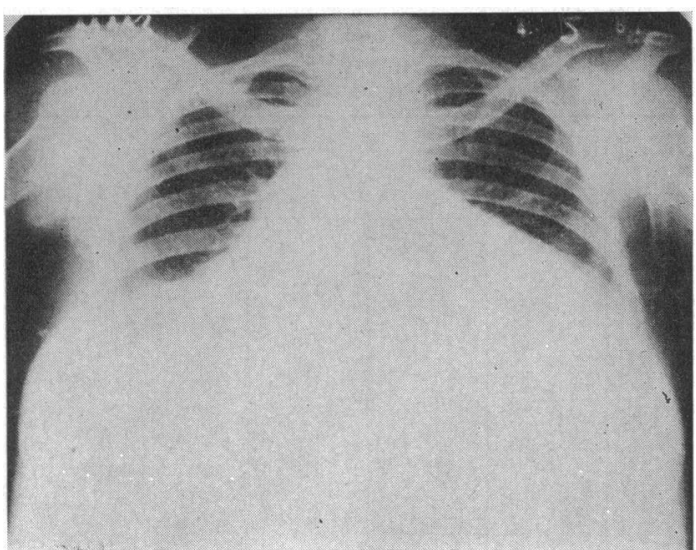

FIG. 2.-Chest radiograph of Case 2 showing enlargement of the cardiac shadow, mainly due to right atrial dilatation. At necropsy $500 \mathrm{ml}$. of transudate were found in the pericardial sac. where peritoneal, pericardial, and pleural adhesions were conspicuous. In the latter case, the ascitic fluid had a milky appearance. Diffuse fibrous thickening of the capsules of the liver and spleen (perihepatitis and perisplenitis) was present in all cases. Congestive splenomegaly was also present and the liver showed other evidence of prolonged and severe passive congestion, such as centrolobular hæmorrhage, diffuse septal fibrosis, and nodular regeneration of the parenchyma. Congestive changes in the lungs were slight. In Case 3 there was a recent pulmonary infarct involving the lower half of the left inferior lobe.

The main findings were present in the heart. Pericardial transudate varied from 50 to $500 \mathrm{ml}$. in amount. The epicardial surface showed frequent "milk spots", but no depression or sulcus was found. The hearts were enlarged due to a considerable degree of dilatation of the right atria and slight hypertrophy of both ventricles. The impressive change was a marked fibrous thickening of the endocardium which also involved the inner third or half of the myocardium (Fig. 3 and 4). The distribution and degree of this fibrous change can be seen in Table V. Usually it affected the inflow tract of the ventricles, practically sparing the outflow tract which in turn was dilated. The atrial thickening was always less severe than that of the ventricle. The fibrous tissue was whitish, porcelain-like, dense, sometimes with foci of calcification and varying in thickness from 0.1 up to

TABLE IV

Gross Extracardiac Findings in four CASES of Endomyocardial Fibrosis

\begin{tabular}{l|c|c|c|c|c|c}
\hline $\begin{array}{l}\text { Case } \\
\text { No. }\end{array}$ & $\begin{array}{c}\text { Ascites } \\
(\mathrm{ml} .)\end{array}$ & $\begin{array}{c}\text { Spleen weight } \\
(\mathrm{g} .)\end{array}$ & $\begin{array}{c}\text { Liver weight } \\
(\mathrm{g} .)\end{array}$ & Perihepatitis & Perisplenitis & Cirrhosis \\
\hline 1 & 12,000 & 700 & 1020 & + & + & ++ \\
2 & 6,000 & 820 & 2240 & ++ & ++ & +++ \\
3 & $13,000^{*}$ & 450 & 1050 & +++ & +++ & +++ \\
4 & 13,500 & 110 & 900 & ++ & ++ & + \\
\hline
\end{tabular}

* Chylous ascites

TABLE V

Gross Findings in the Heart in four Cases of Endomyocardial Fibrosis

\begin{tabular}{c|c|c|c|c|c|c|c}
\hline \multirow{2}{*}{$\begin{array}{c}\text { Case } \\
\text { No. }\end{array}$} & $\begin{array}{c}\text { Heart weight } \\
\text { (g.) }\end{array}$ & \multicolumn{5}{|c|}{ Fibrous thickening of endomyocardium } & \multicolumn{1}{c}{$\begin{array}{c}\text { Intracardiac } \\
\text { thrombosis }\end{array}$} \\
\cline { 2 - 7 } & RV & RA & LV & LA & Valves & RA \\
\hline 1 & 400 & +++ & +++ & ++ & ++ & Mitral & RA \\
2 & 380 & +++ & ++ & - & - & No & No \\
3
\end{tabular}

* Ball thrombus 


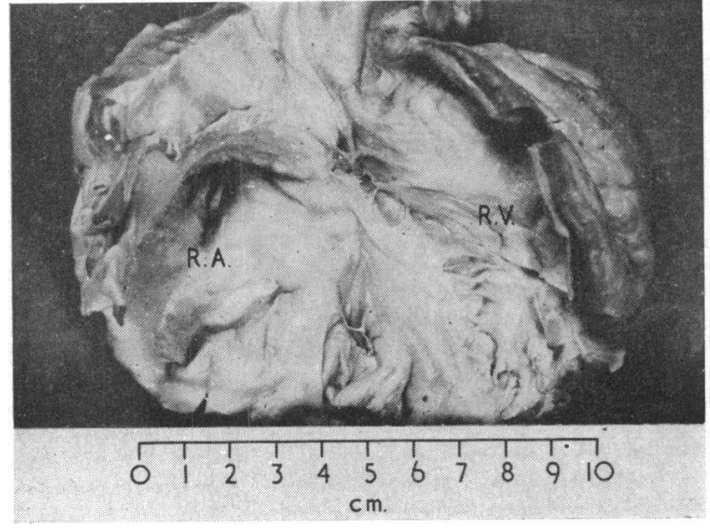

FIG. 3.-Endomyocardial fibrosis involving the right ventricle.

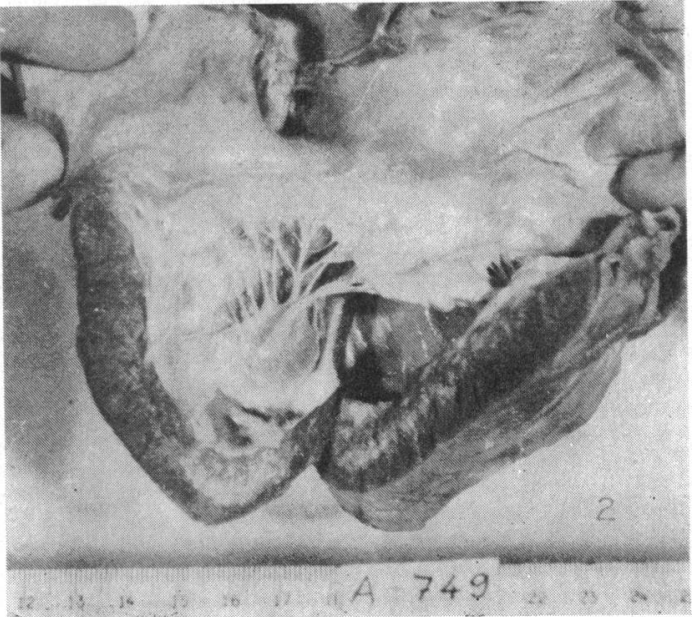

FIG. 4.-Endomyocardial fibrosis involving the left ventricle and part of a leaflet of the mitral valve. Note extension of the fibrous tissue to the myocardium.

$0.3 \mathrm{~cm}$., not including the diffuse extensions to the myocardium. The surface of the involved ventricle or atrium was smooth, the uneven pattern of the papillary muscles being totally obliterated. Organizing thrombi were found in the right atrium in three cases, one of them (Case 3) presenting a ball thrombus of $5.5 \mathrm{~cm}$. in diameter. The extension of the fibrous endocardial tissue to the underlying myocardium was the rule and it consisted of a diffuse fine fibrosis with a hazy periphery. No change was found in the coronary arteries, in the coronary ostia, or in the valvular apparatus. Only in Case 1 were there fibrous changes in one leaflet of the mitral valve. Changes in other

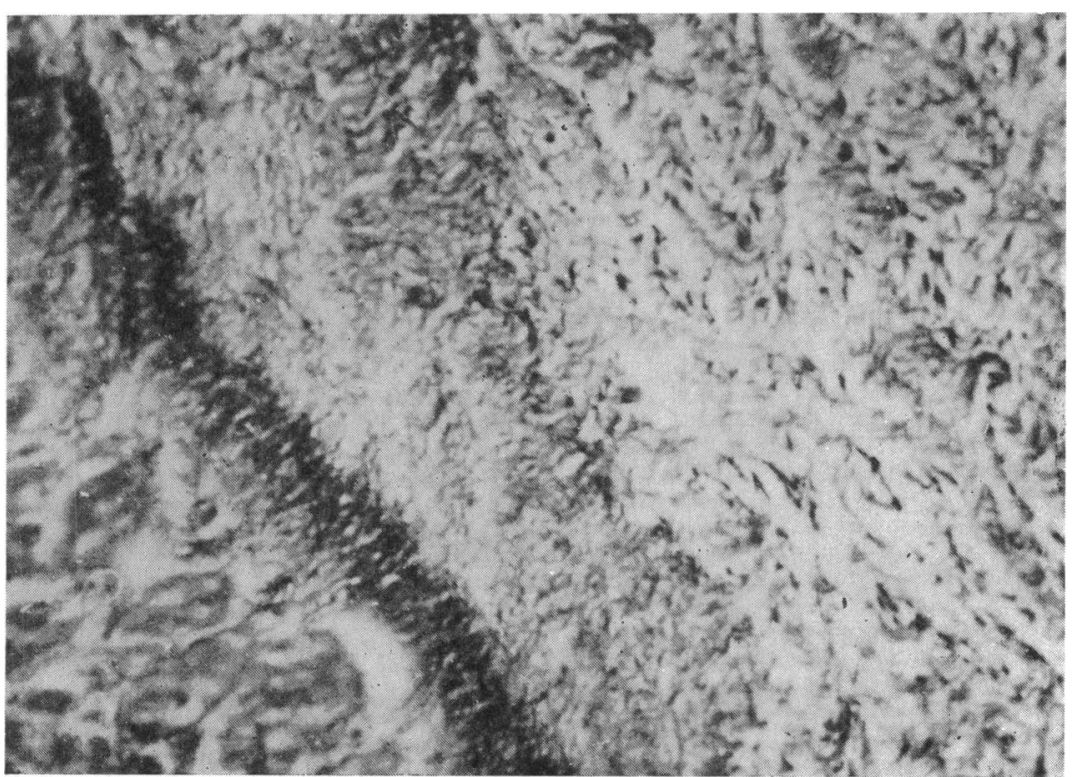

Fig. 5.-The fibrosed endocardium shows scattered elastic fibres. (Weigert's resorcin-fuscin method. $\times 120$.) 


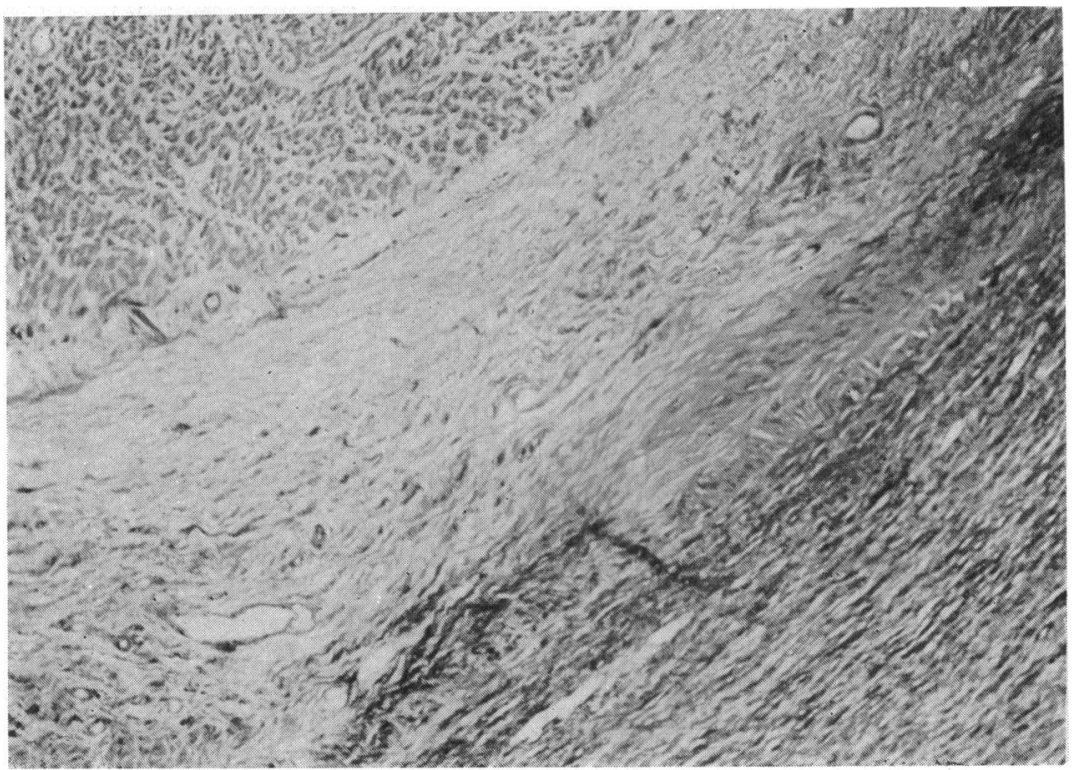

FIG. 6.-Elastic hyperplasia (elastosis) present on the superficial layer of the thickened endocardium. (Weigert's elastica. $\times 120$.)

organs were the consequences of passive congestion. Case 1 presented severe schistosomiasis due to $S$. mansoni, with intestinal, hepatic and pulmonary lesions.

Microscopically, the endocardial fibrous tissue was rich in collagen fibres and poorly cellular. However, there were areas of granulation tissue, others with organizing fibrin deposits and still others showing quite young connective tissue with a large amount of homogeneous ground

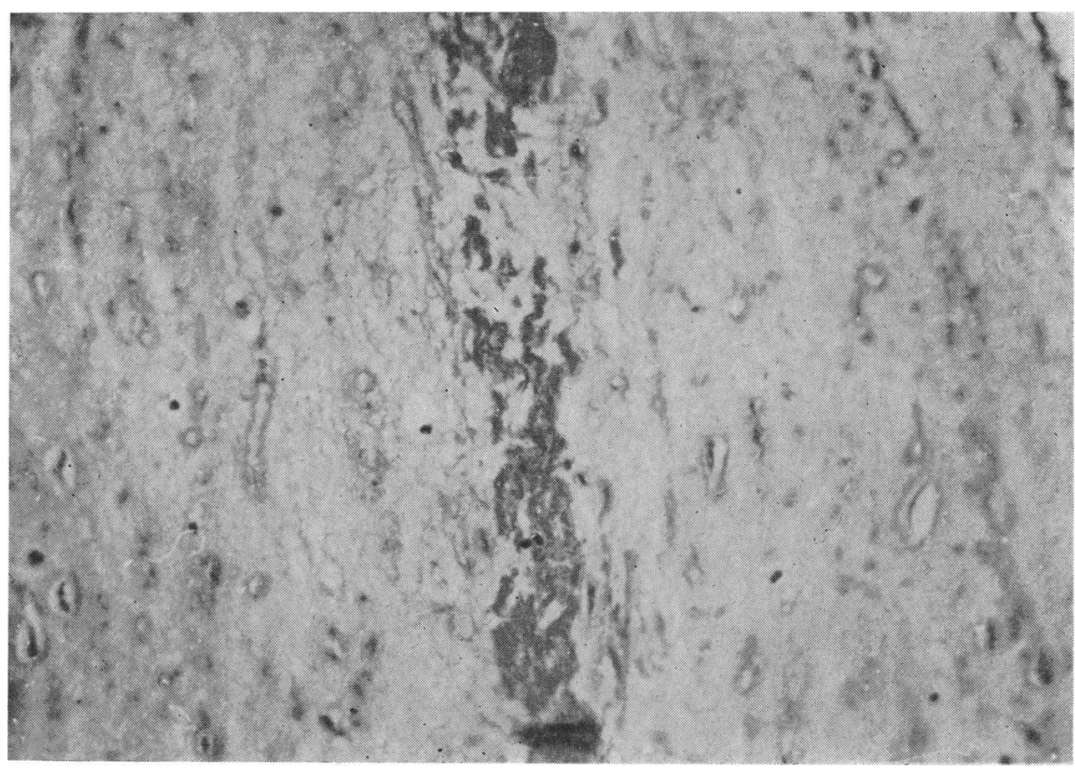

FIG. 7.-Fibrin deposition inside the fibrous tissue of the endocardium. $($ H. and E. $\times 120$. 


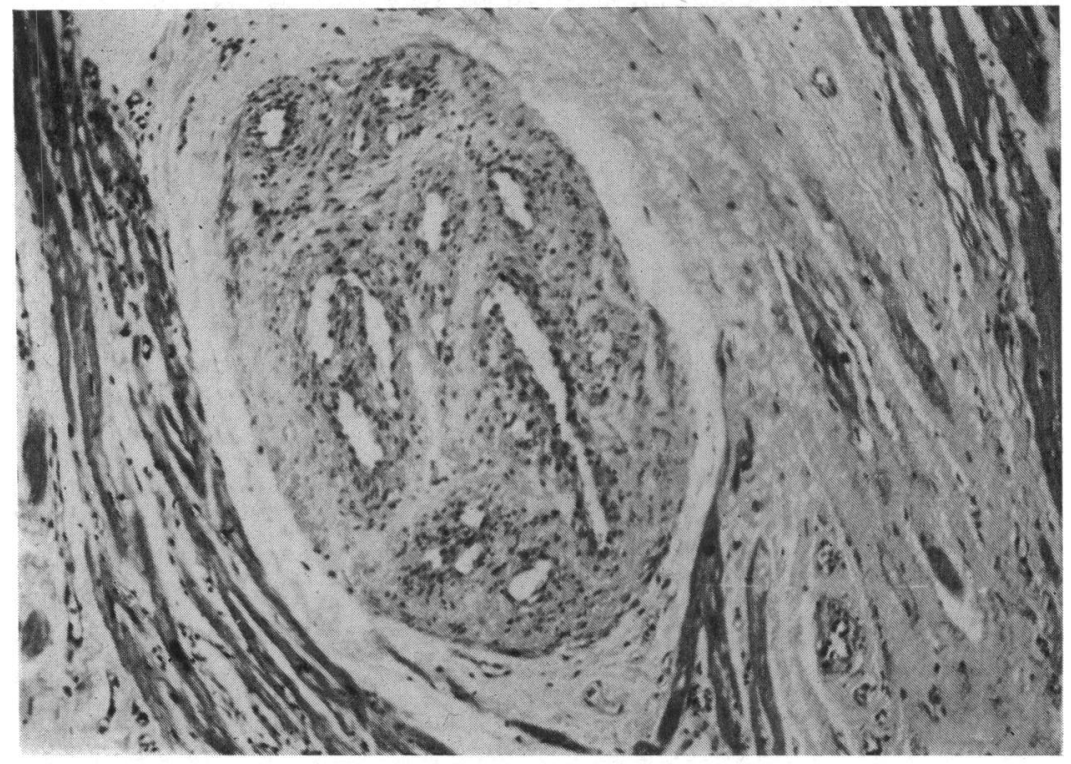

FIG. 8.-Thrombosis with organization and recanalization seen in endomyocardial blood vessel of Case 1. (H. and E. $\times 430$.)

substance, stainable with alcian blue. Sometimes the latter areas were found deeply situated in the fibrosed endocardium, suggesting that the incorporation of fibrous tissue might continue inside the endocardium after the superficial layers were densely collagenized. Elastic tissue was scarce. It was usually present as a dense, long and fine layer along the endomyocardial limits (Fig. 5) with scattered fibres throughout the fibrosed endocardium. In Case 4, there was hyperplasia of elastic fibres, but in an area situated above a dense endocardial fibrous thickening (Fig. 6). Vascular changes in the endomyocardial area were represented by focal intimal fibrous thickening plus variable degrees of medial and adventicial fibrosis. In Case 1 recanalized thrombi were frequently found in medium-sized arteries (Fig. 7). These latter changes were not found in other areas of the heart or elsewhere. Inflammatory changes consisted only in slight lymphocytic and reticular infiltration, especially along the endomyocardial borders and sometimes exhibiting a perivascular distribution. Polymorphonuclear eosinophils were absent. Search for parasites in all heart sections was negative.

\section{COMmENTS}

Endomyocardial fibrosis occurring in northern Brazil is reported for the first time. Its clinical and pathological aspects are similar to those described elsewhere (Davies, 1960; Abrahams, 1962; Fagundes, 1963) and need no further elaboration. It is important to emphasize, however, that in the state of Bahia, Brazil, from where our cases came, there is a large population of African descendants, sometimes living under similar climatic and economic conditions to many natives in Africa. It would be interesting to investigate whether the pathology is similar in these two geographical regions. Another obscure type of heart disease, sometimes described as "cryptogenic heart disease" (Higginson, Isaacson, and Simson, 1960), has already been reported in Bahia (Guimarães and Andrade, 1962).

Endomyocardial fibrosis seems to be a relatively rare condition among us, since the four cases reported here were taken from a total of 1510 necropsies $(0 \cdot 26$ per cent). If the clinical features are carefully looked at, there should be no confusion in the differential diagnosis with our most com- 
mon cause of primary myocardial failure, namely Chagas' myocarditis. In the first place, heart failure in endomyocardial fibrosis, as seen in our cases, presented a prolonged course, usually of more than two years. Furthermore, the rarity of embolic phenomena, the cardiogram showing mainly low voltage of the QRS complex, and the considerable enlargement of the right atrium seen on radiographs, favour the diagnosis of endomyocardial fibrosis. In Chagas' myocarditis (Laranja et al., 1956) and also in the so-called cryptogenic heart disease (Guimarães and Andrade, 1962) the clinical course is more rapid, generally lasting no more than one year, embolic accidents are frequent, and the electrocardiogram shows interference with both the formation and conduction of the stimulus.

Endomyocardial fibrosis involving the right ventricle has been recognized to simulate constrictive pericarditis clinically (Abrahams, 1962; Fagundes, 1963). In our cases such a resemblance was also a morphological one as far as the extracardiac findings were concerned. The severe ascites and the fibrous thickening of the capsules of the liver and spleen ("Zuckerguss") were reminiscent of Pick's disease seen in association with constrictive pericarditis. Little attention has been paid to these extracardiac findings in endomyocardial fibrosis, but they were striking and constant in our cases and in our opinion should be considered as an important feature of the disease.

The presence of fibrin deposition in the endocardium and its incorporation into the fibrous tissue, as seen in our material, suggests that this may be an important pathway in the formation of the endocardial scar, as proposed by Black-Schaffer (1957). However, the presence of young connective tissue showing evidence of active proliferation and deeply situated in the endomyocardial limits, suggests that the increase in fibrous tissue of the endocardium may also take place from below. The cause of the fibrin deposition and the proliferation of young connective tissue in our cases as well as in others, however, remains unknown.

\section{SUMMARY}

A clinical and pathological study of four cases of endomyocardial fibrosis in Bahia, Brazil, is reported. Patients presented a prolonged course of cardiac failure with dyspnœea and ascites as the main symptoms. Endocardial fibrosis involved the right and sometimes the left ventricle and extended to the inner third or half of the myocardium. Embolic phenomena were rare. It may be of importance to note that in the state of Bahia, Brazil, there is some ethnic, climatic, and socioeconomic resemblance to African regions where endomyocardial fibrosis has been reported.

\section{REFERENCES}

Abrahams, D. G. (1962). Endomyocardial fibrosis of the right ventricle. Quart. J. Med., 31, 1.

Black-Schaffer, B. (1957). Infantile endocardial fibroelastosis. A suggested etiology. Arch. Path., 63, 281.

Davies, J. N. P. (1960). Some considerations regarding obscure diseases affecting the mural endocardium. Amer. Heart J., 59, 600 .

Fagundes, L. A. (1963). Endomyocardial fibrosis: report of three cases in southern Brazil. Rev. Inst. Med. trop. S. Paulo, $5,198$.

Faruque, A. A. (1963). Adult endomyocardial fibrosis in Britain. Lancet, 2, 331.

Guimarães, A. C., and Andrade, Z. A. (1962). Miocardiopatia de etiologia obscura. (Relato anátomo-clínico de cinco casos.) Hospital Rio de J., 62, 1023.

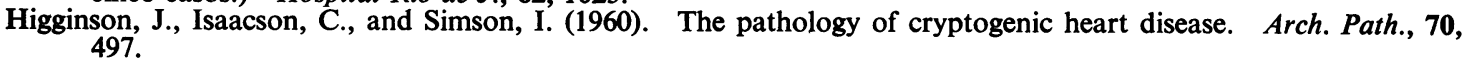

Ishak, K. G., and Tschumy, W. O., Jr. (1962). Endomyocardial fibrosis. Report of a case in a twelve-year-old youth. Amer. J. Med., 32, 645.

Laranja, F. S., Dias, E., Nobrega, G. and Miranda, A. (1956). Chagas' disease. A clinical, epidemiologic and pathologic study. Circulation, 14, 1035.

Lynch, J. B., and Watt, J. (1957). Diffuse endomyocardial sclerosis. Brit. Heart J., 19, 173.

Mattos, A. G., Achutti, A., Fagundes, L. A., Lima, C. P., and Faraco, E. (1963). Endomyocardial fibrosis. [In Portuguese.] Arch. bras. Cardiol., 16, 67.

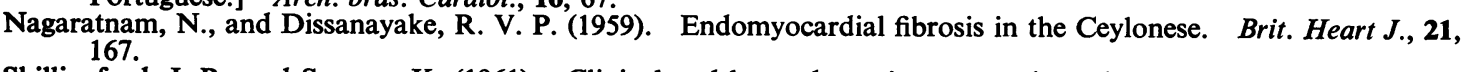

Shillingford, J. P., and Somers, K. (1961). Clinical and hæmodynamic patterns in endomyocardial fibrosis. Brit. Heart J., 23, 433. Turner, P. P., and Manson-Bahr, P. E. C. (1960). Endomyocardial fibrosis in Kenya and Tanganyika Africans.
Brit. Heart J., 22, 305. 